\title{
What Career Benefits can Mentoring Truly Bring for Protégé? Evidence from Meta-Analysis
}

\author{
Zhihui CHENG \\ Hubei University of Economics, 8\# Yangqiao Lake \\ Avenue, \\ Canglong Development Zone, Wuhan, P. R. China
}

Jingtao FU*

Hainan University, 58\#Renmin Avenue, Meilan District, Haikou, P. R. China

*Corresponding author

\author{
Yi HAN \\ Zhongnan University of Economics and Law, 182\# \\ Nanhu Avenue, \\ East Lake High- tech Development Zone, Wuhan, P. R. \\ China
}

\begin{abstract}
Mentoring has been regarded as an effective approach to develop human resources in organizations, for its close association with the career development and growth of both mentor and protégé. Mentoring is conducive to benefit newcomers or protégés' career via providing vocational support, psychosocial support and role modeling. Results from a meta-analysis of 83 independent samples $(\mathrm{N}=13,614)$ documented in the relevant empirical literatures revealed that mentoring was positively related to job satisfaction, organizational commitment, task performance, OCB, career prospects, career satisfaction, but turnover. Moreover, the relationship between mentoring and compensation was not so robust. Finally, contributions and limitations were also discussed.
\end{abstract}

Keywords-Mentoring; Mentor; Protégé; Career benefits; Meta-analysis

\section{INTRODUCTION}

Mentoring is defined as "an intense interpersonal exchange between a senior experienced colleague (mentor) and a less experienced junior colleague (protégés)" (Russell \& Adams, 1997). Not only enterprises but countries worldwide attach great importance to it. In fact, evidences from many aspects have testified the importance of mentorship. The mentorship has influence not only on the mentors and protégés, but on the organization as a whole. For the protégés, it may influence their job satisfaction, organizational commitment, turnover intention, and career success (Allen et al., 2008). For the mentors, it may influence their inner satisfaction and respect, career promotion, supportive network establishment, and improvement of work performance (Allen, Poteet \& Burroughs, 1997). For the organization, it may have an impact on the reduction of turnover, organization communication, management development, organization performance, productivity and socialization (Ragins \& Scandura, 1997).

According to Wanberg, Welsh \& Hezlett (2003), previous research mainly focused on its influence on protégés' career success (approximately 96\%), whereas its influences on mentors and organization are $13 \%$ and $3 \%$, respectively(1). Meanwhile, some researchers have done systematic reviews on the mechanism of mentoring (see Allen \& Eby, 2007; DuBois \& Karcher, 2005; Ragins \& Kram, 2007; Fletcher \& Mullen, 2012), masses of qualitative studies (Chandler, Kram \& Yip, 2011; Haggard, et al., 2011) or meta-analysis studies(Allen et al., 2004; Ghosh \& Reio Jr., 2013).However, very limited literatures have comprehensively explored protégés' career benefits associated with mentoring, especially on how mentoring comprehensively influence protégés' work attitudes, performance and career success.

To fill in this gap, this paper aims to uncover the influence of mentoring on protégés via meta-analysis of Hunter and Schmidt (2004). We estimated the true effect size of each dimension of mentoring on protégés' job satisfaction, organizational commitment, task performance, OCB, career prospect, career satisfaction and compensation. Our research model is depicted in Fig.1

\section{THEORY AND HYPOTHESES}

\section{A. The Structure of Mentoring}

Kram(1983) argued that mentorship consisted of psychological support and vocational support. Later, Burke (1984) proposed a three- dimension model of mentoring: vocational support, psychological support and role modeling. This three-dimension model of mentoring has gained widespread attention in mentoring or mentorship research (Wanberg, Welsh, \&Hezlett, 2003).

Vocational support emphasizes on coaching on jobs provided by mentors to their protégés, such as sponsorship, protection, exhibition, coaching. This dimension has more to do with work itself, can directly prompt protégés' growth and progress in organization, helping them make career planning. Psychological support refers to mentor's psychological function to help protégés establish a sense of identification, competency and efficacy, such as friendship and parent role, social gathering persuasion, acceptance or confirmation. .Role modeling refers to mentor as protégés' model and example to influence and

\footnotetext{
(1) Wanberg,Welsh,\& Hezlett(2003) counted the influences of mentoring on protégés, mentor and organization and considered the overlap section, because some studies involve two or three aspects.
} 
motivate them, and protégés even consider their mentor to be the person they desire to be. Due to the interaction between mentor and protégés, the knowledge and technique expertise, positive values, psychological states and behaviors of mentors are mimic objectives for protégés (Scandura, 1992). In sum, it is necessary to explore the influence of each dimension of mentoring on protégés.

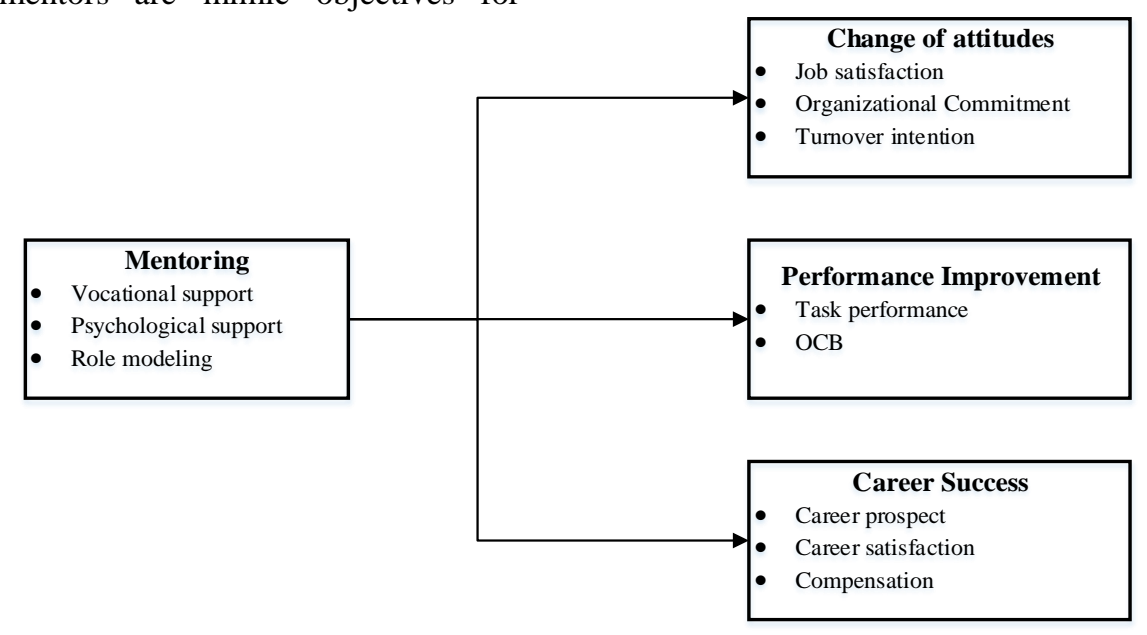

Figure.1 Research model

\section{B. The Influence of Mentoring on Protégés}

\section{1) The Influence of Vocational Support on Protégés}

As is shown in previous studies, vocational support has significant impact on protégés' work satisfaction, organizational commitment and turnover intention. In addition, it also has significantly positively related to task performance and organizational citizenship behavior (Eby et al., 2013). Through sponsorship, protection, exhibition, coaching, and assigning challenging jobs, mentors can directly prompt protégés' growth and progress in organizations, helping them to realize career goals. For example, Sosik and Godshalk (2000) found that mentor can prompt protégés to show high attendance rate, organizational commitment, jog satisfaction and low turnover intention via vocational support. Allen et al.(2004)also revealed in a meta-analysis study that mentoring has significant predictive effect on protégés' subjective career success(e.g. job satisfaction) and objective career success (e.g. promotion, compensation). Besides, some other studies also found mentoring may have significant influence on job performance (Lapierre, Naidoo, \& Bonaccio, 2012), OCBs (Kwan et al., 2011), and career prospect (Day \& Allen, 2004). Hence, we hypothesize that:

H1: Vocational support is positively related to protégés' (a) job satisfaction, (b) organizational commitment, (c) turnover intention, (d) task performance, (e) OCB, (f) career prospect, (g) career satisfaction, (h) compensation.

2) The Influence of Psychological Support on Protégés

Similar to vocational support, psychological support's influence on protégés' benefits has also been well held by empirical studies. Psychological support is represented by friendship, persuasion, acceptance, fellowship and parent role. It is from an informal perspective that we focus on mentor's care and support for his/her protégés. The mentor can change the protégés' attitudes via friendship, acceptance and parent role, and raise protégés' performance and career satisfaction via persuasion and fellowship, but he/she cannot prompt protégés' objective career success(e.g. compensation) (Allen et al., 2004). Thus, psychological support may not have effect on protégés' objective career success, but may have influence on protégés' work attitudes, performance and subjective career success. Besides, Lankau, Carlson and Nielson (2006) found that psychological support may have significant influence on protégés' job satisfaction and organizational commitment. Similarly, Yang (2006) indicated that psychological support has influence on protégés' work performance. In addition, many studies have shown that psychological support may influence career satisfaction and career prospect(Sosik \& Godshalk, 2004; Zhou, et al., 2009).

H2: Psychological support is positively related to protégés' (a) job satisfaction, (b) organizational commitment, (c) turnover intention, (d) task performance, (e) $O C B,(f)$ career prospect, $(g)$ career satisfaction, but (h) compensation.

3) The Influence of Role Modeling on Protégés

In contrast, a very limited number of researches explored the influence of role modeling. According to schema theory, it is assumed that protégés are positioning their expectation, satisfaction, behavior and mentorship quality via discerning and imitating mentor's behavior and work pattern(Kwan, Miao \& Zhang, 2010). The protégés may be quite concerned about mentor's behavior model, know about how their mentor interact with people and how to achieve career success and way of living and working. As such, protégés will imitate their mentor's work and living pattern into theirs. Ensher et al. (2001) found that role modeling will improve protégés' career satisfaction and job satisfaction. A longitudinal study by Chun et al.(2012) shows that mentor's psychological support have significant influence on protégés' organizational commitment in consulting companies. However, relevant studies indicated that role modeling has relatively weak negative impact on protégés' turnover 
intention (Lankau \& Scandura, 2002). Similarly, it has been shown that role modeling was weakly related to protégés' subjective career success, but almost not related to protégés' objective career success (Scandura, 1992). Hence, we hypothesize that:

H3: Role modeling is positively related to protégés' (a) job satisfaction, (b) organizational commitment, (c) turnover intention, (d) task performance, $(e) O C B,(f)$ career prospect, $(\mathrm{g})$ career satisfaction.

\section{METHODOLOGY}

To overcome the limitation of traditional literature review and estimate the true effect sizes of mentoring on protégés' career benefits, this paper adopted Hunter and Schmidt's meta-analysis procedure, which have been proved effective in correcting artifacts, such as sampling error and measurement error (Hunter \& Schmidt, 2004).

\section{A. Literature Retrieval and Criteria for Inclusion}

We did a comprehensive search on the extant empirical studies about mentoring in the workplace. First of all, we input key words and titles, such as apprenticeship, mentoring, coaching, mentorship, mentee, protégés, into English literature databases, such ABI/INFORM, EBSCO, JSTOR, Science Direct, Blackwell, Emerald, Springer, ProQuest, and CNKI and Wangfang in China ; Secondly, we adopt Google Scholar to supplement studies that we might missed via key words used in initial search; Thirdly, we did a systematic arrangement on literature review papers, classical articles, and research manuals; then, according to references listed, we expand the sample for meta-analysis via hands-on searching ; Fourthly, we conducted literature retrieval on papers and works published by Allen, Scandura and their colleagues. As masters of mentorship study and founder of creating mentoring questionnaire, Allen and Scandura conducted many researches on this domain. Meanwhile, to avoid publication bias, we input the same key words about mentoring to search unpublished conference proceedings and dissertations. Though the above steps, we finally got 183 quantitative studies from 1984 to 2013, among them 5 are from Chinese.

Then, according to Hunter and Schmidt's rules, we considered the following criteria for inclusion: i) give priority to empirical studies; ii), mentoring must be the key concept in the article, and it must be clearly measured based on three-dimension model; iii)coefficients or data that can be transformed into coefficients must be reported in the articles, such as t-value, $z$-value. In addition, we verified the situation of using same sample in different papers by combining them into one study. In sum, we got 85 independent samples from 81 literatures, including seven dissertations and one research report. All valid samples added up to 13,614 individual data(1).

\section{B. Sample Data Coding}

For better coding the literatures involved, we developed a special literature coding table, including publication information (authors, time, types), sample characteristics (sample sizes, domains), research

\footnotetext{
Among all 81 literatures involved, 2 papers involved 2 studies each. Hence, there are 85 independent samples or size effect in total.
}

methodology (data sources, coefficients, variable reliability). The codes are developed by two expertise researchers in mentoring studies in a back-to-back way. Before coding, we carefully consider the meanings that authors expressed, and leave those codes blank, whose information are not given or cannot be inferred from the articles. The internal consistency of the two coders reached approximately $91 \%$. For those divergent items, the coders were asked to re-read the article, look up to relevant information with rigid discussion, come to an agreement and obtained the final coding results. Then, we only select the effect size of earliest publication when more than one publication reported the effect sizes among same variables. Besides, we eliminated those studies that reported the coefficients of variables with mentoring as a whole, rather than each dimension of mentoring. We also reported the fail-safe $\mathrm{k}$ number to solve the "file drawer problem".

\section{Statistical Operation of Meta-analysis}

According to Hunter and Schmidt's procedures with random effect model, we firstly reported best estimate of the population correlation $(\bar{r})$ and covariance of a variable with a composite $(\mathrm{rxY})($ see Hunter \& Schmidt, 2004, p.81, formula 3.1). Then, we use the reliabilities of each variable to adjust the measurement error of the coefficient, and get the corrected coefficient. If the reliabilities of some variables are not reported, we replace them by the average reliability. If the literatures only reported some dimension reliability of a variable, we apply the weighted average to get its reliability. Finally, we conducted estimations on the $80 \%$ credibility interval and $95 \%$ confidence interval of the targeted coefficients.

\section{Analysis and Results}

According to Hunter and Schmidt's Meta-analysis procedures, we adopted the paid Hunter-Schmidt Program Package (Version 2.0), Comprehensive Meta Analysis (version 2.0) to testify our hypotheses. Results are shown in Tables 1 to 4 .

\section{E. The Structure Model of Mentoring}

As is shown in Table1, vocational support is positively related to psychological $\operatorname{support}(\rho=.65)$ and role modeling $(\rho=.66)$, and psychological support is also positive related to role modeling $(\rho=.59)$, their $95 \% \mathrm{CI}$ of their true coefficients didn't include 0 , indicating their significant level reaching to p-values below .05. In addition, the $80 \% \mathrm{CR}$ of the true size effects of the three dimensions also didn't contain 0 , which means there exists no heterogeneity among studies.

\section{F. Protégés' Benefits Associated with Vocational Support}

Cohen (1988) divided the effect size of coefficients into three categories: small(.10), medium(.30), and large(.50). As is shown in Table 2, the true effect sizes between vocational support and protégés' work attitude are robust. Vocational support are positively related to organizational commitment $(\rho=.40)$ and job satisfaction $(\rho=.37)$, and is negatively related to turnover intention $(\rho=-.23)$, but not significant. Similarly, vocational support are positively related to task performance $(\rho=.26)$, organizational citizenship behavior $(\rho=.33)$, career 
prospect $(\rho=.28)$, career $\operatorname{satisfaction}(\rho=.36)$ and compensation $(\rho=.23)$. Besides, the $80 \%$ CR of vocational support with relevant variables for the actual coefficients do not contain 0 either, indicating there does not exist heterogeneity among studies or moderators among these relationships. Hence, hypotheses $\mathrm{H} 1(\mathrm{a} \sim \mathrm{b}, \mathrm{d} \sim \mathrm{h})$ was support, but H1(c) was not.

TABLE 1. RESULTS OF STRUCTURE MODEL OF MENTORING

\begin{tabular}{|c|c|c|c|c|c|c|c|c|}
\hline Functions & $\mathrm{N}$ & $\mathrm{k}$ & $\bar{r}$ & $\rho$ & $\mathrm{SD} \rho$ & $95 \% \mathrm{CI}$ & $80 \% \mathrm{CR}$ & fail-safe k \\
\hline VS on PS & 13614 & 73 & .54 & .65 & .15 & {$[.59, .62]$} & {$[.43, .81]$} & 13841 \\
\hline PS on RM & 5689 & 29 & .49 & .59 & .20 & {$[.65, .70]$} & {$[.38, .81]$} & 2465 \\
\hline RM on VS & 5689 & 29 & .56 & .66 & .22 & {$[.61, .66]$} & {$[.47, .86]$} & 7459 \\
\hline
\end{tabular}

Note: VS=vocational support, $\mathrm{PS}=$ psychological support, $\mathrm{RM}=$ role modeling, $\mathrm{N}=$ sample size; $\mathrm{k}$-number of independent studies; $\bar{r}=$ mean sample size weighted observed correlations; $\rho=$ actual effect size; SD $\rho=$ standard error of $\rho ; \quad C R=$ credibility interval; $\quad C I=$ confidence interval; $\quad$ Fail-safe $k=$ number of unlocated studies with non-significant effect sizes that would have to exist to make $\rho$ non-significant.

TABLE 2. RESULTS PROTÉGÉS’ BENEFITS ASSOCIATED WITH VOCATIONAL SUPPORT

\begin{tabular}{|c|c|c|c|c|c|c|c|c|}
\hline Vocational Support & $\mathrm{N}$ & $\mathrm{k}$ & $\bar{r}$ & $\rho$ & $\mathrm{SD} \rho$ & $95 \% \mathrm{CI}$ & $80 \% \mathrm{CR}$ & fail-safe $k$ \\
\hline \multicolumn{9}{|l|}{ Work attitudes } \\
\hline Organizational commitment & 2211 & 12 & .34 & .40 & .20 & {$[.38,47]$} & {$[.20, .60]$} & 1497 \\
\hline Job satisfaction & 2952 & 16 & .30 & .37 & .21 & {$[.29, .36]$} & {$[.10, .63]$} & 1208 \\
\hline Turnover intention & 2498 & 11 & -.18 & -.23 & -.15 & {$[-.24, .16]$} & {$[-.46, .04]$} & 400 \\
\hline \multicolumn{9}{|l|}{ Work Performance } \\
\hline Task performance & 2006 & 12 & .23 & .26 & .11 & {$[.19, .28]$} & {$[.13, .39]$} & 338 \\
\hline $\mathrm{OCB}^{\mathrm{a}}$ & 1251 & 5 & .27 & .33 & .08 & {$[.24, .32]$} & {$[.25, .40]$} & 2520 \\
\hline \multicolumn{9}{|l|}{ Career Success } \\
\hline Career prospect $^{\mathrm{b}}$ & 2908 & 16 & .23 & .28 & .18 & {$[.20, .28]$} & {$[.05,51]$} & 680 \\
\hline Career satisfaction $^{c}$ & 3047 & 14 & .30 & .36 & .11 & {$[.28, .35]$} & {$[.22, .50]$} & 1106 \\
\hline Compensation & 908 & 6 & .19 & .23 & .09 & {$[.12, .26]$} & {$[.12, .34]$} & 43 \\
\hline
\end{tabular}

Note: $\mathrm{N}=$ sample size; k-number of independent studies; $\bar{r}=$ mean sample size weighted observed correlations, $\rho=$ actual effect size; SD $\rho=$ standard error of $\rho ; \mathrm{CR}=$ credibility interval; $\mathrm{CI}=$ confidence interval; Fail-safe $\mathrm{k}=$ number of unlocated studies with non-significant effect sizes that would have to exist to make $\rho$ non-significant; ${ }^{a} \mathrm{OCB}=$ organizational citizenship behavior , which includes data of contextual performance; ${ }^{\mathrm{b}} \mathrm{Career}$ prospect includes data of promotion prospect, promotion opportunity; ${ }^{\mathrm{c}}$ Career satisfaction includes data of subjective career success.

\section{G. Protégés' Benefits Associated with Psychological Support}

In Table 3, we can see that psychological support are positively related to organizational commitment $(\rho=.40)$ and job satisfaction $(\rho=.29)$, but negatively related to turnover intention $(\rho=-.17)$. Similarly, psychological support are positively related to task performance $(\rho=.32)$, organizational citizenship behavior $(\rho=.29)$, career $\operatorname{prospect}(\rho=.19)$ and career satisfaction $(\rho=.19)$, but is not related to compensation $(\rho=.05)$. In apparent contrast with vocational support, the relationship between psychological support and compensation is far from exact or robust. Besides, the $95 \%$ CI of the actual coefficient of psychological support and compensation contains 0 and the coefficient is below the criteria of 0.1 , which means the actual size effect is not significant under the p-value below .05. In addition, the $80 \%$ CRs of psychological support with turnover intention and career satisfaction contain 0 , indicating that there exist possible moderators between the relationship of psychological support with the two variables. Hence, hypotheses H2(a g) was support, but $\mathrm{H} 2$ (h) was not.

\section{H. Protégés' Benefits Associated with Role Modeling}

As is shown in Table 4, Role modeling is positively related to organizational commitment $(\rho=.40)$ and job satisfaction $(\rho=.29)$, but is not related to turnover intention $(\rho=-.10)$. Moreover, role modeling are positively related to task performance $(\rho=.33), \operatorname{OCB}(\rho=.29)$, career $\operatorname{prospect}(\rho=.12)$ and career satisfaction $(\rho=18)$. Besides, there exists possible moderators between role modeling and career prospect. Hence, hypotheses $\mathrm{H} 1(\mathrm{a} \sim \mathrm{b}, \mathrm{d} \sim \mathrm{g})$ was support, but H3(c) was not.

\section{CONCLUSIONS AND DISCUSSION}

\section{A. Conclusions}

Using Hunter and Schmidt's psychometric Meta-analysis, we examined the influence of mentoring on protégés' career benefits in almost 30 years (1984-2013). We found that mentoring have different influence on protégés' change of attitudes, performance improvement and career success.

\section{1) The Influence of Mentoring on Protégés' Change of} Attitudes

Mentoring is positively related to job satisfaction and organizational commitment, but its relationship with 
turnover intention is not robust. According to fit theory, some protégés who initially fit in with their mentors may eventually leave mentors. Static fit theory cannot give effective explanations for the constant changing external environment as well as the expectations and incentives between mentor and protégé. The establishment and maintenance of effective mentoring depends on trust, commitment, loyalty, responsibility, flexibility and support. It means the continuance of length of mentoring may influence the quality of mentoring. In the four stages of mentoring development (enlightenment, cultivation, separation, re-orientation), the differences of emotional experience, career development, personal needs between mentor and protégé may also change the influence of mentoring on protégés' organizational commitment. We only testified the relationship between mentoring and protégé' organizational commitment in static contexts, rather than uncover the changes of commitment and satisfaction in different stages of mentoring. Besides, it is revealed in a longitudinal study of Lankau and sandura(2004) revealed that vocational support and psychological support have significant negative effect on protégé's turnover intention, but role modeling has no effect on turnover intention .

\section{2) The Influence of Mentoring on Protégés'} Performance

Previous studies indicated that mentoring has a closer and more stable effect on protégés' work performance. This finding were supported by literatures in China and the west (Day \& Allen, 2004). Job demand-resource model emphasized that job resources will impact individual work performance. On the one hand, organizations in modern society require many objective job demands for individuals, including physical, psychological and social demands (e.g. time pressure, work loading, emotional intelligence); On the other hand, it will raise employee's performance when they seek for more resource support (e.g. physical, psychological and social resources). Vocational supports from mentors include sponsoring, protection, exhibition, coaching and assigning challenging tasks. Psychological support, such as friendship, parent role, persuasion, fellowship, acceptance, mentor's recognition and care for protégés, will increase protégés' dependence and sense of belongings, thus improving their work performance. Role modeling influences and motivates protégés, making them take mentors as the person that they expect to be.

3) The Influence of Mentoring on Protégés' Career Success

The influence of mentoring on protégés' subjective career success is robust, but its influence on protégés' objective career success doesn't come to an agreement. The actual coefficients of vocational support, psychological support and role modeling with career satisfaction are $.36, .16$ and .18 , respectively. Although mentoring has significant effect on protégés' subjective career success, yet the effect sizes of each dimension are different. The relevance of vocational support with subjective career success are highest of all, and its coefficients with career prospect and career satisfaction are $.28, .36$, respectively. The influence of psychological support on subjective career success is secondary, and its coefficients with career prospect and career satisfaction both are .19. Role modeling has weak positive influence on subjective career success, and its coefficients with career prospect and career satisfaction are .12 and .18 , respectively. In contrast, the effects of mentoring on protégés' objective career success are quite different. Vocational support has significant positive effect on protégés' objective career success but has no effect on protégés' objective career success.

\section{B. Contributions}

First of all, as to the theoretical contribution, we found that mentoring can not only change protégés' work attitudes, raise their work performance, but contribute to protégés' career success, especially subjective career success. This paper testified the relationship between mentoring and protégés' career benefits, hence providing deep deconstruction and re-interpretation of the simple logic proposition-the mentoring- protégés' benefits from construct level. Besides, mentors will also pass on work skills or interpersonal interaction skills to their protégés, assign challenging tasks to them, and urge them to acquire new skills to improve work performance. Moreover, mentors will act like parents or role model to give their protégés advice or persuasion. Through establishing the parent-like relationship, the mentor immense their protégés, urge them to explore self-development and career development model, transfer their recognition and care to protégés, which may not only change protégés' attitudes, but increase their career satisfaction, raise their career expectation, and gain more promotion and higher compensation.

Secondly, this paper also has its practical implications. We testified that mentoring does have effective influence on protégés' career benefits. Specifically, mentoring will influence some aspects of protégés' work attitudes, work performance, even career success. Hence, enterprises are supposed to recognize the importance of mentoring in essence, and effectively enact it in developing employees. Meanwhile, management should be aware that not every dimension of mentoring has the same effects on protégés' career benefits, for example, psychological support will reduce protégés' turnover intention, while vocational support and role modeling does not. 
TABLE 3. RESULTS OF PROTÉGÉS’ BENEFITS ASSOCIATED WITH PSYCHOLOGICAL SUPPORT

\begin{tabular}{|c|c|c|c|c|c|c|c|c|}
\hline Psychological Support & $\mathrm{N}$ & $\mathrm{k}$ & $\bar{r}$ & $\rho$ & $\mathrm{SD} \rho$ & $95 \% \mathrm{CI}$ & $80 \% \mathrm{CR}$ & fail-safe $k$ \\
\hline $\begin{array}{l}\text { Work attitudes } \\
\begin{array}{l}\text { Organizational } \\
\text { commitment }\end{array}\end{array}$ & 2810 & 16 & .35 & .40 & .18 & {$[.34, .38]$} & {$[.17, .63]$} & 1397 \\
\hline Job satisfaction & 2757 & 14 & .25 & .29 & .28 & {$[.23, .30]$} & {$[.01, .57]$} & 703 \\
\hline Turnover intention & 2381 & 11 & -.14 & -.17 & -.21 & {$[-.18,-.10]$} & {$[-.38, .04]$} & 113 \\
\hline Work Performance & & & & & & & & \\
\hline Task performance & 1823 & 11 & .28 & .32 & .18 & {$[.25, .34]$} & {$[.10, .54]$} & 445 \\
\hline OCB & 1251 & 5 & .24 & .29 & .11 & {$[.18, .30]$} & {$[.15, .42]$} & 99 \\
\hline Career Success & & & & & & & & \\
\hline Career prospect & 3848 & 15 & .16 & .19 & .14 & {$[.14, .20]$} & {$[.01, .37]$} & 391 \\
\hline Career satisfaction & 2393 & 13 & .16 & .19 & .16 & {$[.13, .20]$} & {$[-.01, .39]$} & 186 \\
\hline Compensation & 600 & 4 & .04 & .05 & .04 & {$[-.01, .06]$} & {$[.00, .08]$} & 0 \\
\hline
\end{tabular}

Note: $\mathrm{N}=$ sample size; k-number of independent studies; $\bar{r}=$ mean sample size weighted observed correlations, $\rho=$ actual effect size; SD $\rho=$ standard error of $\rho ; C R=$ credibility interval; $C I=$ confidence interval; Fail-safe $k=$ number of unlocated studies with non-significant effect sizes that would have to exist to make $\rho$ non-significant.

TABLE 4. RESULTS OF PROTÉGÉS’ BENEFITS ASSOCIATED WITH ROLE MODELING

\begin{tabular}{|c|c|c|c|c|c|c|c|c|}
\hline Role Modeling & $\mathrm{N}$ & $\mathrm{k}$ & $\bar{r}$ & $\rho$ & $\mathrm{SD} \rho$ & $95 \% \mathrm{CI}$ & $80 \% \mathrm{CR}$ & fail-safe $k$ \\
\hline Work attitudes & & & & & & & & \\
\hline Organizational commitment & 1188 & 7 & .41 & .49 & .17 & {$[.39, .51]$} & {$[.28, .70]$} & 394 \\
\hline Job satisfaction & 1473 & 8 & .33 & .40 & .20 & {$[.31, .42]$} & {$[.14, .66]$} & 307 \\
\hline Turnover intention & 1057 & 4 & -.08 & -.10 & .04 & {$[-.13, .01]$} & {$[-.15,-.05]$} & 3 \\
\hline Work Performance & & & & & & & & \\
\hline Task performance & 357 & 2 & .27 & .33 & .00 & {$[.23, .39]$} & {$[.29, .29]$} & 0 \\
\hline OCB & 656 & 3 & .24 & .29 & .00 & {$[.17,32]$} & {$[.29, .29]$} & 28 \\
\hline Career Success & & & & & & & & \\
\hline Career prospect & 636 & 4 & .10 & .12 & .12 & {$[.02, .18]$} & {$[-.04, .26]$} & 6 \\
\hline Career satisfaction & 380 & 3 & .14 & .18 & .00 & {$[.04,24]$} & {$[.18, .18]$} & 3 \\
\hline
\end{tabular}

Note: $\mathrm{OCB}=$ organizational citizenship behavior; $\mathrm{N}=$ sample size; k-number of independent studies; $\bar{r}=$ mean sample size weighted observed correlations, $\rho=$ actual effect size; $\mathrm{SD} \rho=$ standard error of $\rho ; \mathrm{CR}=$ credibility interval; $\mathrm{CI}=$ confidence interval; Fail-safe $\mathrm{k}=$ number of unlocated studies with non-significant effect sizes that would have to exist to make $\rho$ non-significant.

\section{Limitations and Future Research}

As with all meta-analysis, this paper also has its limitations. Firstly, all data source are mainly based on protégés' self-evaluation, few are from mentor's assessment on mentoring, which may bring about common method bias. Hence, it is necessary to adopt multi-source samples on mentoring when uncovering the different effects of mentoring in future. Besides, although we considered the "file drawer problem", yet it is impossible for us to include all papers published and unpublished. Therefore, future research needs to include publications in other languages.

Secondly, our meta-analysis on mentoring mainly focused on Scandura and Ragins's three-dimension Mentoring Function Questionnaire(MFQ) (Scandura \& Ragins,1993) and neglected Noe's Mentoring Function Scale ( Noe,1988), Ragins and McFarlin's Mentoring Role Instrument (Ragins \& McFarlin,1990) and other scales. Future researchers need to integrate these studies, for they may get different actual effect size in contrast to previous studies.

\section{ACKNOWLEDGEMENT}

The author(s) wish to thank the National Science Foundation of China (No. 71502175) and the National Social Science Fund of China (No.14BGL199).

\section{REFERENCES}

(Readers can ask the authors for a complete copy of references for meta-analysis)

[1] T.D. Allen, L.T. Eby, E.Lentz, The Relationship between Formal Mentoring Program Characteristics and Perceived Program Effectiveness, Personnel Psychology, 59(2006)125-153.

[2] S. G.Baugh, E. A.Fagenson-Eland, Boundaryless Mentoring: An Exploratory Study of the Functions Provided by Internal versus External Organizational Mentors, Journal of Applied Social Psychology, 35(2005)939-955

[3] R. Ghosh, \& T.G. Reio Jr, Career Benefits Associated with Mentoring for Mentors: A Meta-analysis, Journal of Vocational Behavior, 83(2013)106-116.

[4] D. L. Haggard, T. W. Dougherty, D. B. Turban, et al. Who Is a Mentor? A Review of Evolving Definitions and Implications for Research. Journal of Management, 37(2011)280-304.

[5] C. Hu, E. K.Pellegrini, T. A. Scandura, Measurement Invariance in Mentoring Research: A Cross-Cultural Examination across Taiwan and the U.S, Journal of Vocational Behavior, 78(2011)274-282. 
[6] J. E. Hunter, L. Schmidt, Methods of Meta-analysis: Correcting Error and Bias in Research Findings (2nd ed.), Sage Publications, Inc, 2004.

[7] H. K. Kwan, Y.N. Mao, H.N. Zhang, The Impact of Role Modeling on Protégés' Personal Learning and Work-to-Family Enrichment, Journal of Vocational Behavior, 77(2010)313-322.

[8] M. J. Lankau, D. S. Carlson, T. R. Nielson, The Mediating Influence of Role Stressors in the Relationship between Mentoring and Job Attitudes, Journal of Vocational Behavior, 68(2006)308-322.

[9] L.M. Lapierre, L.J. Naidoo, S. Bonaccio, Leaders' Relational Self-Concept and Followers' Task Performance: Implications for Mentoring Provided to Followers, Leadership Quarterly, 23(2012)766-774.

[10] E. Lentz, T.D. Allen, The Role of Mentoring Others in the Career Plateauing Phenomenon, Group \& Organization Management, 34(2009)358-384
[11] J. Liang, Y.P. Gong, Capitalizing on Proactivity for Informal Mentoring Received during Early Career: The Moderating Role of Core Self-Evaluations, Journal of Organizational Behavior, 34(2012) 1182-1201

[12] K.A.Smith-Jentsch, J.J.M. Fullick, N.A. Bencaz, Complementary Mentor Motivations and Protégé Characteristics: Determinants of Mentoring, Journal of Organizational Psychology, 12(2012)56-69.

[13] S. Tonidandel, D. T. Avery, M. G. Phillips, Maximizing Returns on Mentoring: Factors Affecting Subsequent Performance, Journal of Organizational Behavior, 28(2007)89-110.

[14] C. R.Wanberg, J. Kammeyer-Mueller, M. Marchese, Mentor and protégé predictors and outcomes of mentoring in a formal mentoring program, Journal of Vocational Behavior, 69(2006)410-423.

[15] C.R. Wanberg, E.T. Welsh, J. Kammeyer-Mueller, Protégé' and Mentor Self-Disclosure: Levels and Outcomes within Formal Mentoring Dyads in a Corporate Context, Journal of Vocational Behavior, 70(2007)398-412. 